International Journal of Scholarly Papers for Media and Communications

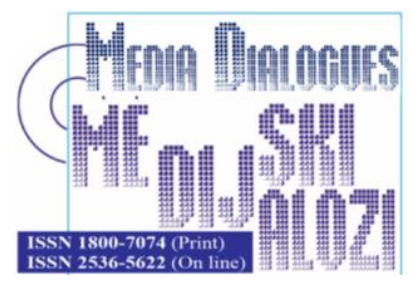

Kashumov, A. (2021), „A View on the European Standards and Bulgarian National Law Related to Hate Speech", Media Dialogues / Medijski dijalozi, Vol. 14, No. 3, pp. 43-49.

\title{
A View on the European Standards and Bulgarian National Law Related to Hate Speech
}

\author{
ALEXANDER KASHUMOV, Media lawyer
}

Deputy President of Ethics Commission on Electronic Media in Bulgaria

\begin{tabular}{|c|c|}
\hline $\boldsymbol{A} \boldsymbol{R} \boldsymbol{T} \boldsymbol{I} \boldsymbol{C L} \boldsymbol{E}$ & Received: April 03, 2020 / Revised from: May 03, 2020 \\
$\boldsymbol{I} \boldsymbol{N} \boldsymbol{F} \boldsymbol{O}$ & Accepted: June 03, 2020 / Available online: January 15, 2021 \\
\hline $\boldsymbol{D O I}$ & doi.org/10.14254/1800-7074/14-1/5 \\
\hline
\end{tabular}

\begin{abstract}
The Article presents the international standards related to "hate speech" and the Bulgarian law and ethic standards with this respect. It presents relevant practice of the European Court of Human Rights and the provisions pertaining to criminal and civil responsibility for incitement to hatred and defamation. On another hand, it points some cases in Bulgaria and suggests some approach to the issues and conclusive remarks.

KEYWORDS: Hate speech, freedom of expression, european convention of human rights, code of ethics, ethnic minorities.
\end{abstract}




\section{INTRODUCTION}

People are able to identify certain expression as hate speech, but meet difficulties to define what hate speech is. Usually it is understood as addressed to a group of people rather than to an individual. That group could be united by different features such as ethnic, race, national, social, religious, sexual or other identity.

From legal point of view hate speech differs from defamation or statement of untrue facts as well as from intrusion in personal privacy. These are related to expression directed towards an individual. On another hand, usually hate speech is connected with discrimination thus valuing a group of people lower than other groups only on the ground of some feature.

Also, this way of speaking could be conveyed through the media or in public spaces such as streets and squares during protests or virtual places like social networks. Geographically there are territories where tension between groups is bigger than in other places and consequently hate speech is more likely to appear and be incentive to other problems. In addition, societies change and problems could sharpen, disappear or arise in a different place dependent on the circumstances. In Bulgaria hate speech is no or only exceptionally used by the media. Even in such cases it is more words or quotation of what do politicians say rather than qualifi- cations given by the media themselves. Also, national and generally the influential newspapers and broadcasts often avoid such topics ${ }^{1}$.

This relatively peaceful situation could be changed in cases of incidents which concentrate public tension. In September 2011 a car accident caused by a guard of well-known businessman killed a young man in a village near the city of Plovdiv. The businessman had been suspected for a long time for producing unauthorized alcohol, but more important the people in that village where his villa was situated were fed up by the arrogant stile of the family. By case that family was of Roma origin so the anger of local people easily grew into hatred expressed by units nationwide against the whole ethnic group. In a couple of weeks the situation gradually was calmed down, but the case raises the question of whether proper laws and effective implementation are in place to handle it. The legal framework and ethical norms and practices in Bulgaria will be in the focus here to give an impression of the system operating in as regards hate speech.

\footnotetext{
${ }^{1}$ See e.g. Alexander Kashumov, Analysis of the information from the database compiled based on the results from monitoring the Bulgarian media for instances of hate speech in the coverage of the anniversary of the Ilinden-Preobrazhenie Uprising in: Hate speech in Bulgarian and Macedonian media: examples, causes and solutions, Sofia 2011, published by the Broadcast Training Center ProMedia Foundation, Sofia and the Media Development Center, Skopje, pp. 19-20 (http://www.osf.bg/ downloads/File/HateSpeech_Report_EN.pdf ).
} 


\section{INTERNATIONAL AND REGIONAL STANDARDS}

Legally as far as expression is a subject, the international standards related to freedom of expression are applicable. The right to freedom of expression is enshrined in Article 19 of the Universal Declaration of Human Rights, Article 19 of the International Covenant on Civil and Political Rights (ICCPR), and Article 10 of the European Convention of Human Rights (ECHR). According to these instruments freedom of expression is regarded as a principle and its restriction is narrowly interpreted. On another hand the International Convention on the Elimination of all the Forms of Racial Discrimination (Racial Discrimination Convention) obliges the states parties to it to criminalize hate speech (Article 4, a).

As regards the European Union (EU) legal framework, there are two directives related to the equality between genders and of ethnic minorities respectively. As binding legislation they oblige the country members to implement the rights and duties provided in their domestic legislation. Bulgaria is party to all these legal instruments as it ratified and published ICCPR already in State gazette No 43 of 1976, the Racial Discrimination Convention in State gazette No 56 of 1992 and ECHR in State gazette No 66 of 1992. It became an EU member since 1 January 2007.

\section{HATE SPEECH AND EUROPEAN FREEDOM OF EXPRESSION STANDARDS}

The more detailed approach to freedom of expression and its restrictions is found in Art.10 of ECHR. The main reason for this is the rich interpretation of this right given by the European Court of Human Rights (ECtHR). This provision declares the right of everyone to freedom of expression, which includes freedom to hold opinions and to receive and impart information and ideas without interference by public authority and regardless of frontiers. These freedoms may be subject to restrictions only in cases the three-part test under Art.10, para. 2 of ECHR is met.

The test includes in the first place the condition that the restrictions should be provided by law. Next, they should be applied only with the purpose to protect other rights and interests listed in Art.10, para.2 of ECHR. These are national security, territorial integrity or public safety, the prevention of disorder or crime, the protection of health or morals, the protection of the reputation or rights of others, preventing the disclosure of information received in confidence, or maintaining the authority and impartiality of the judiciary. The conditions, restrictions and sanctions in this respect should also be "necessary in a democratic society".

Consequently, restrictions to the freedom of expression are legitimate only when all the three elements of the three-part test are in place together. This means that restrictions should be: - provided in the national legal framework; - aiming to protect the rights and interests listed in Art.10, para.2 of ECHR; - "necessity in a de- 
mocratic society". Considering the relation between the freedom of expression and its restrictions, the ECtHR held that: Freedom of expression constitutes one of the essential foundations of a democratic society and is one of the basic conditions for its progress and for the development of every man. It is applicable not only to "information" or "ideas" that are favorably received or regarded as inoffensive or as a matter of indifference, but also to those that offend, shock or disturb the State or any sector of the population. Such are the demands of pluralism, tolerance and broadmindedness without which there is no "democratic society".

According to the practice of the ECtHR, the question of the balance between the freedom of expression and its restrictions include "hate speech" matters as well. In such cases the national authorities are obliged to apply the three-part test. As to the question of what is the protected interest in such cases, the Strasbourg authorities have found that it could be "the reputation and rights of the ethnic groups", but in any case national authorities are obliged to maintain a sound legal framework ensuring effective measures for "respect for freedom of expression with respect for human dignity and the protection of the reputation or the rights of others ${ }^{4}$."

As any other expression, cases of hate speech are subject to assessment whether measures, restrictions, sanctions are provided by law, following one or more legitimate aims and "necessary in a democratic society". The latter includes assessment of the "pressing social need" and "proportionality" for imposing the measure.

The national authorities are in all cases obliged to take into account the context and contents of the publication at question. Even when a publication exposes certain country in a very negative light or contains hostile connotations, this is not sufficient to justify restriction of the right to freedom of expression. In order to conclude that a case involves hate speech, it should seek to arouse deep or irrational hatred against those presented as responsible for the given situation ${ }^{5}$.

\section{NATIONAL LEGAL FRAMEWORK ON HATE SPEECH, INSULT AND DEFAMATION. CONSTITUTION}

The right of everyone to hold opinions and disseminate it via various means is enshrined in Article 39 of the 1991 Constitution. According to paragraph 2 this right cannot be used to the detriment of the rights and reputation of others and for incitement to forcible change of the constitutional order, to hatred or violence against per-

\footnotetext{
${ }^{2}$ The famous passage is referred to in a number of ECtHR decisions: cf. Handyside v. UK judgment from 7 December 1976, para.49, Sunday Times v. UK judgment from 26 April 1979, para.65 and others.

${ }^{3}$ See for example Balsytè-Lideikienè v. Lithuania judgment from 4 November 2008, para.73.

${ }^{4}$ Principle 2 of Appendix to Recommendation no. R (97) 20 of the Committee of Ministers to Member States on "Hate speech", drafted within the framework of the Council of Europe, referred to in the ECtHR case- law.

${ }^{5}$ Cf. Bingöl v. Turkey judgment from 22 June 2010, para.38.
} 
sonality. Therefore a "hate speech" exemption from freedom of expression is introduced at a constitutional level. The freedom of the media from censorship is guaranteed under Article 40, while Article 41 provides the right of everyone to seek, receive and impart information while its second paragraph gives the citizens the right to obtain government held information.

The right to freedom of expression is guaranteed also by Article 19 of the International Covenant on Civil and Political Rights and Article 10 of the ECHR, which are ratified by Bulgaria and by the force of the Constitution considered part of the domestic legislation. Therefore they are directly applicable, which is of particular importance in cases of conflict of rights or legal provisions. In such cases the international instruments always take precedence ${ }^{6}$.

The rights under Articles $39-41$ of the Constitution were interpreted by the Constitutional Court in its Decision № 7 from 4 June, 1996, on constitutional case № 1/1996. The court held that in all these provisions the right shall be considered as the principle and the restrictions as the exception from the principle. Restrictions can be applied only with the aim to protect competitive rights and interests and should be interpreted narrowly.

\section{CRIMINAL LIABILITY FOR HATE SPEECH}

According to Article 162, para. 1 of the Penal Code, a person who propagates or incites discrimination, violence or hatred based on racial, national or ethnic affiliation is subject to sanction. Such an action represents a criminal offense if it is performed through print or other media as well as through electronic information systems (what is most probably meant here is internet). The penalty is imprisonment from one to four years. It was made graver in April 2011, which raised concern within the media for possible abuse in cases of criticism against government or politicians ${ }^{7}$. The possibility of criminal prosecution against protestors shouting anti-Roma statements in some Bulgarian cities in September 2011 contributed to the short end of the story. In fact, opening criminal cases on this ground happens very rarely in Bulgaria.

\section{CRIMINAL RESPONSIBILITY FOR INSULT AND SLANDER}

Like in most European legal systems, Bulgarian law distinguishes between defamation as statement of untrue facts and insult understood as speech/expression diminishing someone's dignity. Article 146 of the Penal Code defines insult as criminal offense. One who says something degrading to someone's honour and dignity is punishable with a fine of up to 3,000 BGN (approximately 1500 EUR). According to Article 147 defamation which means stating untrue and defaming facts about

\footnotetext{
${ }^{6}$ Art.5, para.4 of the Constitution.

${ }^{7}$ See e.g. an interview in the daily 24 hours: http://www.24chasa.bg/Article.asp?ArticleId=653032
} 
someone or ascribing to him a crime is punished with a fine 3,000 to $7,000 \mathrm{BGN}$. In cases of publication the criminal offences are subject to more severe punishment. The fine is between 3,000 and 10,000 BGN and public reprimand. In criminal cases civil claim for damages could be filed by the alleged victim.

Insult or libel cases could be started only by the initiative of the affected person and are not prosecuted ex officio since 2000. Nevertheless such cases against journalists are not very rare. Statistics of the Bulgarian Helsinki Committee shows 131 pending cases in 2001. The number combines both criminal and civil court cases.

\section{LIABILITY FOR DISCRIMINATORY SPEECH}

The EU directives in the field of equality between men and women and the Racial Equality Directive 2000/43/EC were implemented by the special Protection Against Discrimination Act (PADA), published in State gazette No 86 of 2003. The law sets a prohibition of any direct or indirect discrimination on grounds of gender, race, nationality, ethnicity, human genome, citizenship, origin, religion or belief, education, convictions, political affiliation, personal or social status, disability, age, sexual orientation, marital status, property status, or on any other grounds established by law or by an international treaty to which the Republic of Bulgaria is a party. Special commission on discrimination operates under the law and considers complaints of discrimination.

Although rare, there have been cases under PADA where individuals or NGOs complained of discrimination performed by public statement. In 2005 the Sofia Regional Court found that with his public declaration the leader of the Labour Union Podkrepa, had committed incitement to discrimination and harassment on the basis of ethnicity. The court qualified this way Mr. Trenchev's appeal that every Bulgarian should use weapon to fight "Roma criminality". In his decision the judge concluded that the appeal to raise arms against "Roma criminality" generated a perilous environment ${ }^{8}$.

\section{HATE SPEECH ETHICAL STANDARDS}

The Code of Journalistic Ethics of the Bulgarian Media adopted in 2005 by a group of the most influential print and electronic media contains a section titled "Discrimination". It does contain the following principles:

2.5.1. We respect everyone's right to live in security and safety, and we shall avoid publications that incite or encourage hatred, violence or any form of discrimination.

\footnotetext{
${ }^{8}$ See at: http://bulgaria.indymedia.org/article/33477
} 
2.5.2. We shall not refer to anyone's race, colour, religion, ethnic affiliation, sexual orientation, mental or physical condition, unless it is of substantial significance to the meaning of the information ${ }^{9}$.

In 2008 the Ethics Commission on Print Media drafted recommendations related to the manner in which the problems of ethnic, religious and other communities are to be presented. The commission emphasized that "hostile speech" demonstrates lack of journalistic and analytical skills for serious analysis of the social and economic problems of the society ${ }^{10}$.

\section{CONCLUSIVE REMARKS}

"Hate speech" often appears as a problem in transitional societies. Even if cases are not in place, strong legal norms and their implementation are necessary to prevent growing hatred and public tension on racial, ethnic or similar ground. However, such conflicts of rights should be approached dili-gently, not allowing undue interference with freedom of expression and pressure on the free debate on public matters. The best way to ensure that media refrain from such a language is by developing ethic standards and practices, leaving the role of public prosecution and courts only for exceptional cases of "pressing social need".

\section{BIBLIOGRAPHY}

Kashumov, A. (2011), "Analysis of the information from the database compiled based on the results from monitoring the Bulgarian media for instances of hate speech in the coverage of the anniversary of the Ilinden- Preobrazhenie", Uprising in: Hate speech in Bulgarian and Macedonian media: examples, causes and solutions, Sofia - Skopje: 2011, The Broadcast Training Center ProMedia Foundation, The Media Development Center, pp. 19-20.

\section{Web pages}

http://www.24chasa.bg/Article.asp?ArticleId=653032

http://bulgaria.indymedia.org/article/33477

http://www.mediaethics-bg.org/index.php?do=17\&lang=bg

$\mathrm{http} / / / \mathrm{www}$.mediaethics-bg.org/index.php?do=31\&id=12

\footnotetext{
${ }^{9}$ Available at: http://www.mediaethics-bg.org/index.php?do=17\&lang=bg

${ }^{10}$ The recommendation is available at http://www.mediaethics-bg.org/index.php?do=31\&id=122
} 